\title{
Spatial and temporal patterns of juvenile stone flounder Kareius bicoloratus growth rates during and after settlement
}

\author{
Kirk D. Malloy ${ }^{1, *}$, Yoh Yamashita ${ }^{2}$, Hideaki Yamada $^{2}$, Timothy E. Targett $^{1}$ \\ 'University of Delaware, Graduate College of Marine Studies, Lewes, Delaware 19958, USA \\ ${ }^{2}$ Tohoku National Fisheries Research Institute, 3-27-5 Shinhama, Shiogama, Miyagi 985, Japan
}

\begin{abstract}
Spatial and temporal differences in habitat characteristics of coastal nursery grounds can have a large impact on growth rate, survival, and subsequent recruitment of species with estuarinedependent early life history stages. Stone flounder Karelus bicoloratus is a temperate North Pacific flatfish species characterized by large recruitment variability and an estuarine-dependent juvenile stage. Post-larvae settle from mid-January to early April in inshore and estuarne nursery grounds, and juvenules subsequently move farther inshore using selective tidal stream transport. Laboratory studies were conducted to determine the sensitivity of juvenile stone flounder growth rates to changes in temperature and feeding rates, at conditions common during settlement $\left(8^{\circ} \mathrm{C}\right)$ and post-settlement $\left(12^{\circ} \mathrm{C}\right)$. The relationship between RNA:DNA ratio and growth rate was developed in the laboratory, and was used to measure in situ growth rates of juveniles from 5 different habitats during settlement (March) and after (April). Juvenile stone flounder in the laboratory grew relatively quickly feeding ad libitum at $8^{\circ} \mathrm{C}$ $\left(4.1 \%\right.$ body weight $\left.\mathrm{d}^{-1}\right)$ and $12^{\circ} \mathrm{C}\left(7.0 \% \mathrm{bw} \mathrm{d}^{-1}\right)$, but growth rate was very sensitive to changes in feeding rate at both temperatures. Growth rate of starved juveniles was not significantly different between 8 and $12^{\circ} \mathrm{C}$ and averaged $-1.3 \%$ bw d $\mathrm{d}^{-1}$. RNA:DNA ratios were good predictors of growth rate $\left(\mathrm{R}^{2}=\right.$ 0.88 ), with temperature as a covariate. In situ growth rates at all 5 stations (1 estuary, 1 seagrass bed, and 3 deeper inshore settlement areas) were higher in April than in March. In situ growth rates were highest during both months at the low-salınity estuarine station where fish had highest gut fullnesses. Growth rates were also high at a deeper inshore station near a sewage treatment outfall characterized by higher prey abundances than those typically found in open water areas of Sendai Bay, Japan. Growth rates were consistently lowest at the vegetated (Zostera spp. bed) habitat, although retention in this habitat between March and April was high. Spatial differences in sediment grain size and prey abundances may be the primary factors responsible for the large variability in habitat-specific growth rates. Temperature-corrected comparisons of growth limitation suggest that discrete habitats maintain their relative values as nursery grounds over time, although the magnitude of growth limitation was much greater during settlement (March) than post-settlement (April).
\end{abstract}

KEY WORDS: Stone flounder Kareius bicoloratus Growth Habitat RNA:DNA Recruitment

\section{INTRODUCTION}

Variability in growth and survival rates of early life history stages is considered one of the primary mechanisms controlling annual recruitment and therefore adult population sizes in fishes (Cushing 1975, Sis-

\footnotetext{
- Present address: Northeastern University, Department of Biology، 414 Mugar Hall, Boston, Massachusetts 02115, USA. E-mail: kmalloy@lynx.neu.edu
}

senwine 1984). Annual recruitment can vary considerably, exerting a strong influence on the fluctuations observed in marine fish population sizes. Such dramatic fluctuations in recruitment are thought to be caused by relatively subtle changes in factors affecting the growth and survival rates of early life history stages (May 1974, Houde 1987, 1989). Specifically, small spatial and temporal changes in abiotic factors (such as temperature, salinity, turbidity), biotic factors (predator and prey population sizes), and habitat qual- 
ity (presence of vegetation, sediment characteristics, current patterns) can greatly affect the growth and mortality rates of larval and juvenile fishes. Although mortality rates are generally lower for juveniles than for larvae, the juvenile stage is usually more prolonged and therefore total mortality of juveniles can equal or exceed that during the larval stage (Smith 1985 Folkvord \& Hunter 1986, Kaeding \& Osmundson 1988). Additionally, the juvenile stages of many species are dependent on inshore estuaries, which naturally vary both spatially and temporally in their value as nursery habitats and are extremely vulnerable to anthropogenic modification

The primary cause of mortality during the juvenile stage is thought to be predation (Cushing 1974, Houde 1987. Bailey \& Houde 1989). Rapid growth is vital for juvenile fishes to reduce their vulnerability to predation, which has been shown to decrease with increasing size in many species (e.g. Werner et al. 1983, Post \& Evans 1989). Juvenile fishes also increase foraging efficiency with growth as a result of increased swimming speeds, larger mouth gapes, and an increased choice of appropriate-sized prey (e.g. Bindoo 1992, Ghan \& Sprules 1993)

Therefore, the availability of juvenile nursery grounds suitable for optimal foraging and avoiding predation has a large impact on growth and mortality rates and subsequent recruitment. Assessment of those characteristics of optimal nursery habitats is critical to understanding how spatial and temporal fluctuations in environmental variables can affect recruitment and therefore adult population sizes. Several habitat characteristics have been found to be important to growth and survival of juvenile fishes, including temperature, salinity, turbidity, sediment grain size, prey availability, and the presence of vegetation (Burke 1991, Burke et al. 1991, Malloy \& Targett 1991, Sogard 1992, Lankford \& Targett 1994). Many studies have documented the importance of habitat characteristics, particularly submerged vegetation, to successful foraging, predator avoidance and survival of juvenile fishes (Orth \& Heck 1980, Rozas \& Odum 1988, Sogard 1992).

Stone flounder Kareius bicoloratus is a temperate North Pacific pleuronectid that supports important commercial and recreational fisheries throughout the coastal waters of Japan. Recent decreases in adult population size are thought to be the result of overfishing and highly variable annual recruitment (Tsuruta 1991). Adults spawn offshore (20 to $50 \mathrm{~m}$ depth) during December and January, larvae $(10$ to $15 \mathrm{~mm}$ total length, TL) settle during February and March in coastal waters, and subsequently immigrate to inshore nursery grounds (Tsuruta 1978, 1991). Although juveniles are found at highest densities in shallow $\left(\leq 2 \mathrm{~m}\right.$ depth) brackish water 8 to $12^{\circ} \mathrm{C}$ on fine to coarse sand (Omori et al. 1976. Yusa et al. 1977), they occur in a wide variety of habitats, including inshore seagrass beds, mudflats, as well as deeper $(10$ to $15 \mathrm{~m})$ areas with relatively low benthic productivity (Yusa et al. 1977. Yamashita et al. in press). Juvenile stone flounder mortality rates are extremely high immediately following settlement (Yusa et al. 1977, Yusa 1981) and may have a substantial impact on annual recruitment. In addition to a high mortality rate, absolute mortality of juveniles is probably substantial because estuarine residence lasts for about 5 mo (Omori \& Tsuruta 1988).

Because stone flounder settle in heterogeneous habitats when temperatures are low, spatial and temporal changes in temperature and prey availability may have a large impact on post-settlement survival and subsequent recruitment. However, there are no data describing the sensitivity of growth rates in this species to different temperatures and variable feeding rates. Additionally, specific habitats may differ in their value as nursery areas, and an understanding of which habitats contain fast-growing individuals may reveal the critical components of stone flounder nurseries. Some nursery grounds contain dense submerged vegetation (primarily Zostera spp.), which may provide important predation refuges as well as microhabitats for prey items. In spite of the reported value of vegetated habitats to other juvenile fishes, their importance as flatfish nurseries is not clear. Non-vegetated habitats may be better nurseries for flatfish due to their benthic habits and requirement for suitable burying substrate.

This study examined the spatial and temporal patterns of growth and feeding of juvenile stone flounder in 3 coastal settlement areas and 2 estuarine nursery habitats. The relative importance of temperature and food availability to growth rates of newly settled and juvenile stone flounder was determined in laboratory experiments. RNA:DNA ratios of fish were developed as correlates of growth rates in laboratory experiments, and used to determine in situ growth rates of juveniles from the 5 different habitats in and around Sendai Bay, Japan, during March and April 1992. Spatial and temporal patterns in the degree of growth limitation were used to develop hypotheses regarding important habitat characteristics of stone flounder nursery grounds and post-settlement distribution patterns.

\section{MATERIALS AND METHODS}

Laboratory experiments. Newly settled juvenile stone flounder were collected with a push net $(79 \times$ $59 \mathrm{~cm}$ ) from Stn 1 (see Table 1, Fig. 1 for description of sampling stations) on March 3,1992 (19 to $28 \mathrm{~mm}$ TL; water temperature 6 to $8^{\circ} \mathrm{C}$, salinity $15 \%$ for the $8^{\circ} \mathrm{C}$ 
Table 1 Station characteristics, sample sizes and densities of stone flounder Karelus bicoloratus used to determine in situ RNA:DNA ratios and growth rates in and around Sendai Bay, Japan. Salinity is range for March-April on the bottom. N: number of samples analyzed for RNA:DNA ratıos. $A D$ : instantaneous rate of density decrease (defined in 'Materials and methods')

\begin{tabular}{|c|c|c|c|c|c|c|c|c|c|}
\hline Station & Depth & Vegetation & $\begin{array}{c}\text { Salinity } \\
(\%)\end{array}$ & $\begin{array}{c}\text { Collection } \\
\text { dates (1992) }\end{array}$ & $\begin{array}{l}\text { Temp } \\
\left.{ }^{\circ} \mathrm{C}\right)\end{array}$ & $N$ & $\begin{array}{l}\text { Fish density } \\
\left(1000 \mathrm{~m}^{-2}\right)\end{array}$ & $\begin{array}{l}\Delta D \\
\left(d^{-1}\right)\end{array}$ & $\begin{array}{l}\text { Crangon affinis } \\
\text { density }\left(10 \mathrm{~m}^{2}\right.\end{array}$ \\
\hline \multirow[t]{2}{*}{1 (Gamou) } & $10-50 \mathrm{~cm}$ & None & $3-16$ & 15 Mar 92 & 10.8 & 12 & 856.2 & & 0.39 \\
\hline & & & & $24 \therefore$ ipr 92 & 16.5 & 20 & 218.8 & 0.0332 & \\
\hline \multirow[t]{2}{*}{2 (Matsushima) } & $10-50 \mathrm{~cm}$ & Zostera spp. & $25-31$ & $18 \operatorname{Mar} 92$ & 8.0 & 9 & 1022.3 & & \\
\hline & & & & 22 Apr 92 & 12.5 & 8 & 88.7 & 0.0698 & 0.75 \\
\hline \multirow[t]{2}{*}{3 (Matsushima) } & $1-3 \mathrm{~m}$ & None & $30-32$ & $18 \mathrm{Mar} 92$ & 6.8 & 20 & 93.8 & & \\
\hline & & & & 22 Apr 92 & 10.5 & 4 & 4.5 & 0.0868 & 1.1 \\
\hline \multirow[t]{2}{*}{4 (Airport) } & $10 \mathrm{~m}$ & None & $29-33$ & 23 Mar 92 & 7.2 & 17 & 1635.2 & & \\
\hline & & & & $14 \operatorname{Apr} 92$ & 8.5 & 21 & 50.6 & 0.1580 & 6.1 \\
\hline \multirow[t]{2}{*}{5 (Off Torinoumi) } & i) $10 \mathrm{~m}$ & None & $29-33$ & $23 \operatorname{Mar} 92$ & 7.0 & 16 & 442.9 & & \\
\hline & & & & 14 Арг 92 & 8.5 & 16 & 10.2 & 0.1714 & 8.7 \\
\hline
\end{tabular}

experiment, and on April 16, 1992 (20 to $38 \mathrm{~mm}$ TL; water temperature 9 to $10.5^{\circ} \mathrm{C}$, salinity $16 \%$ ) for the $12^{\circ} \mathrm{C}$ experiment. The size ranges used represent typical size ranges of fish that would experience the experimental temperature in the field ( $Y$ Yamashita pers. obs.). Fish were returned to the laboratory and maintained in 71 of static, aerated, $1 \mu \mathrm{m}$ filtered seawater $(31 \%)$ at 8 or $12( \pm 0.5)^{\circ} \mathrm{C}$. Fish were fed wild zooplankton (primarily calanoid and harpacticoid copepods), Artemia nauplii and fresh chopped tubifex worms ad libitum. Water changes $(50 \%)$ were made every other das.

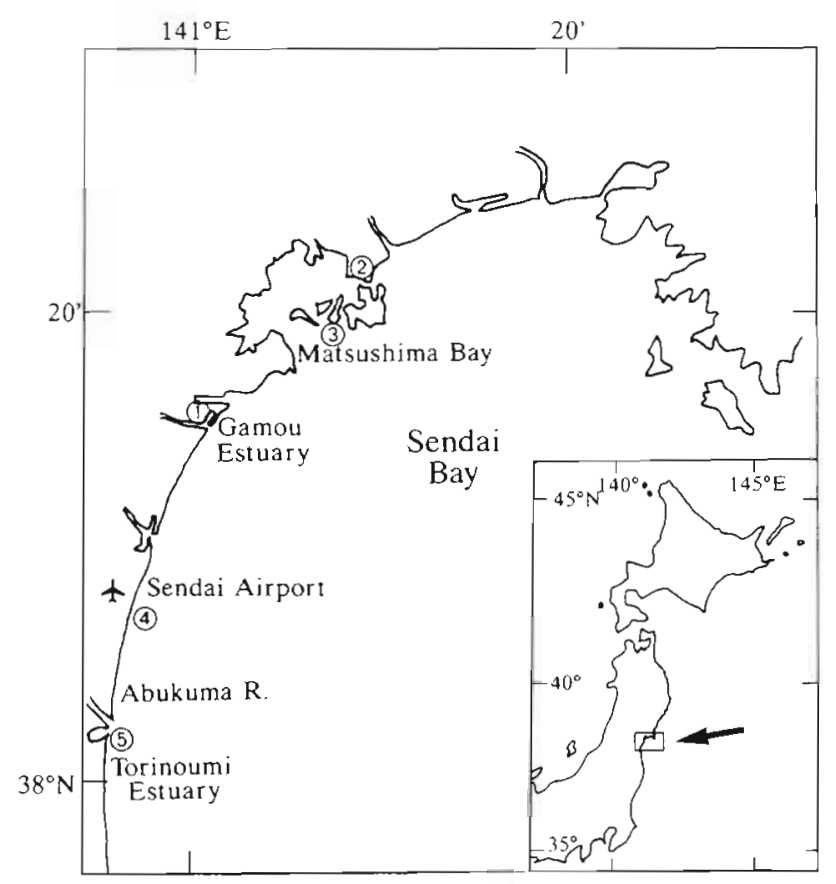

Fig. 1. Location of sampling stations near Sendai Bay, Japan, where juvenle stone flounder were collected for laboratory experiments and determination of in situ growth rates. Station numbers and additional site descriptions are in Table 1
A total of $30\left(8^{\circ} \mathrm{C}\right)$ or $40\left(12^{\circ} \mathrm{C}\right)$ fish were acclimated to temperature and laboratory conditions for $4 \mathrm{~d}$. Fish were then starved for $24 \mathrm{~h}$ to empty their guts, measured to the nearest $\mathrm{mm}$ (TL), blotted with a damp paper towel, and weighed to the nearest $0.0001 \mathrm{~g}$ on a Mettler AE 100 electronic balance (accurate to \pm $0.0002 \mathrm{~g}$ when the same fish was weighed 5 times). Experimental fish were held individually in clear plastic buckets (on black plastic) containing $7 \mathrm{l}$ of filtered seawater with gentle aeration. Diffuse natural light was provided by a large window in the temperaturecontrolled room (March: $11.5 \mathrm{~h}$ light: $12.5 \mathrm{~h}$ dark; April: 13 h light: 11 h dark).

At each temperature, 15 fish (chosen at random) were starved and 15 fish were fed ad libitum for $10 \mathrm{~d}$. Ten additional fish at $12^{\circ} \mathrm{C}$ were fed every other day (approximately $50 \%$ maximum rations) Initial fish lengths and weights within each temperature experiment did not differ significantly among ration treatments ( $t$-test, $8^{\circ} \mathrm{C}$; ANOVA, $12^{\circ} \mathrm{C}$ ). After $10 \mathrm{~d}$, all fish were starved for $24 \mathrm{~h}$ to allow their guts to empty, and weighed and measured as above. Daily specific growth rate $\left[G=\ln \left(W t_{10}\right)-\ln \left(W t_{1}\right) / t_{\text {, where }} W t_{10}\right.$ and $W t_{1}$ are weight on Day 10 and Day 1, respectively, and $t$ is time in days] was calculated for each fish, and was reported as $\%$ body weight $\mathrm{d}^{-1}\left[\left(\mathrm{e}^{\sigma}-1\right) \times 100\right\}$. Mean growth rates at different temperatures and feeding conditions were compared with a 1-way ANOVA $(\alpha=$ $0.05)$.

Immediately after being weighed on Day 10 , each experimental fish was frozen on dry ice and freezedried at $-50^{\circ} \mathrm{C}$ for $48 \mathrm{~h}$ for determination of RNA:DNA. The head, skin and internal organs were removed, and the remaining tissue was powdered for extraction of nucleic acids. RNA and DNA were extracted in ice cold $5 \%$ TCA (trichloroacetic acid), and quantified using a slightly modified protocol of Buckley \& Bulow (1987) (Malloy \& Targett 1994). RNA was quantified by the or- 
cinol reaction, and diphenylamine was used to quantify DNA. Herring sperm DNA and yeast RNA (Boehringer Mannheim) were used as standards for each assay.

The relationship between $G$ and RNA:DNA was determined using multiple linear regression models which initially included $W t_{1}$, temperature, and all potential interaction terms as independent variables. Only terms which improved the fit of the model $\left(\mathrm{R}^{2}\right)$ and which had significance values $(p)<0.05$ were included in the final model.

Field collections. Newly settled and early juvenile stone flounder were collected with a push net $(79 \times$ $59 \mathrm{~cm})$ and beam trawl $(2 \mathrm{~m} \times 30 \mathrm{~cm}$ opening, after Kuipers 1975) from 5 different habitats in Sendai Bay, Japan, during March and April 1992 (see Fig. 1, Table 1). These habitats represented 1 estuary (Stn 1), 1 seagrass bed (Stn 2), and 3 deeper inshore settlement areas. Distance of tows was measured using previously measured markers (e.g. buoys, stakes) and/or calibrated flow meters attached to the beam trawl, and/or measured lengths of towing rope. Beam trawls covered $>1000 \mathrm{~m}^{2}$ at Stns 4 and 5, and 500 to $1000 \mathrm{~m}^{2}$ at all other stations. Sampling efficiencies of nets were not considered in calculating fish densities. Water temperature, salinity, and depth were recorded for each sample, and recording temperature probes were left at Stns 1 and 2. Sediment size composition was determined by sieving sediments from the top $2 \mathrm{~cm}$ through a series of different sized screens, and size distributions were calculated on a percent dry weight basis.

All fish were collected during daylight hours at least $4 \mathrm{~h}$ after dawn to account for possible variability in RNA:DNA caused by diurnal feeding behavior. Some of the juveniles were frozen immediately on dry ice, measured, freeze-dried and analyzed for RNA:DNA ratio as described above. All specimens used for RNA:DNA analysis were post-metamorphic (stages $I_{3}$ to $J_{i}$ Minami 1984, Goto et al. 1989). The remaining juveniles were fixed immediately in $85 \%$ ethanol for analysis of gut contents. Gut contents were dissected from the stomach and intestines at least 2 h after ethanolpreserved fish were placed in seawater to stabilize wet weights. Weights of fish (without gut contents) and gut contents were determined to the nearest $0.0001 \mathrm{~g}$, and gut contents were sorted by taxa and the percentage frequency of occurrence was calculated for each prey type. Gut fullness was calculated as (gut content wet weight/fish wet weight) $\times 100$.

Densities of the predatory shrimp Crangon affinis at some stations were estimated by averaging numbers of individuals in bottom collections at Stns 1 (push net, March and April), 2 (push net, April),
3, 4 and 5 (push net and beam trawl, March and April) in 1992

Recent growth rates of field-caught fish were estimated from RNA:DNA ratios and water temperatures at the time of collection using the regression model developed in the laboratory. Mean estimated growth rates were calculated for each site and sampling date, and compared using a 1-way ANOVA $(\alpha=0.05)$ for each month after assumptions of normality and homogeneous variances were confirmed (Zar 1984). Tukey's multiple comparisons test was used to differentiate statistically among different mean growth rates.

This study did not quantify movement of individuals among habitats, or measure immigration rates due to newly settled individuals. Instead, 'retention' $\left(D_{f} / D_{i} \times\right.$ 100 , where $D_{1}$ is density in March and $D_{f}$ is density in April) and $\triangle D$ the instantaneous rate of density decline $=-\left[\ln \left(D_{f}\right)-\ln \left(D_{i}\right)\right] / t$, where $t$ is time in days $\}$ were used to estimate the change in fish density over time at each station.

\section{RESULTS}

\section{Effects of temperature and ration on growth rates}

Growth rates of juvenile stone flounder in the laboratory were strongly affected by both temperature and feeding rate. Growth rates under ad libitum feeding conditions were significantly higher at 12 than at $8^{\circ} \mathrm{C}$ (Table 2). Mean specific growth rate of juveniles fed $50 \%$ ad libitum at $12^{\circ} \mathrm{C}$ was not significantly different from that of juveniles feeding unrestricted at $8^{\circ} \mathrm{C}$. The mean growth rate of unfed juveniles was $-1.32 \mathrm{~d}^{-1}$, and did not differ significantly between 8 and $12^{\circ} \mathrm{C}$.

\section{RNA:DNA ratios as predictors of growth rate}

RNA:DNA ratios were positively and significantly related to specific growth rates of juvenile stone floun-

Table 2. Karelus bicoloratus. Specific growth rates (SGR) of juvenile stone flounder reared in the laboratory at 2 temperatures and a range of ration levels $1 \%$ ad libitum). Superscripted letters indicate means that are not significantly different as determined by a 1 -way ANOVA and Tukey's multiple comparisons tests

\begin{tabular}{|lccccc|}
\hline $\begin{array}{l}\text { Temperature } \\
\left({ }^{\circ} \mathrm{C}\right)\end{array}$ & $\begin{array}{c}\text { Ration } \\
(\% \text { maximum) }\end{array}$ & $\begin{array}{c}\text { Mean SGR } \\
\left(\% \text { body welght d }{ }^{-1}\right)\end{array}$ & SD & SE & $N$ \\
\hline 8 & 0 & $-1.287^{\circ}$ & 0.428 & 0.111 & 15 \\
8 & 100 & $4.190^{\circ}$ & 1.296 & 0.335 & 15 \\
12 & 0 & $-1361^{\circ}$ & 0.385 & 0.099 & 15 \\
12 & 50 & $4.168^{\circ}$ & 0.840 & 0.266 & 10 \\
12 & 100 & $7.077^{\circ}$ & 1.081 & 0.279 & 15 \\
\hline
\end{tabular}



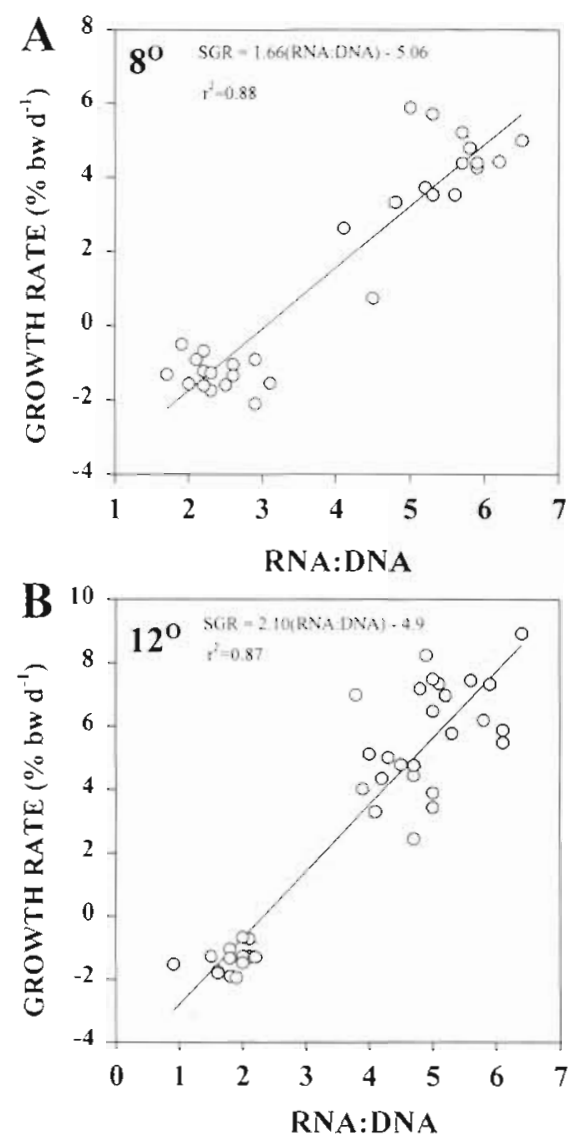

Fig. 2. Kareius bicoloratus. Relationship between RNA:DNA ratio and specific growth rate (SGR) for juvenile stone flounder reared in the laboratory at 2 temperatures. Each point represents a single fish. Solid lines are least-squares linear regressions, and dotted lines are $95 \%$ confidence intervals of the regression lines

der at both temperatures $\left(r^{2} \geq 0.87\right.$; Fig. 2). However, these relationships (i.e. slopes) were significantly different between fish reared at $8^{\circ} \mathrm{C}$ and fish reared at $12^{\circ} \mathrm{C}$ (Fig. 2). Therefore, the best multiple linear regression model predicting growth rate from RNA:DNA ratio included additional independent variables for temperature and for temperature $\times$ RNA:DNA interaction. $G=0.762(\mathrm{RNA}: \mathrm{DNA})+0.039(\mathrm{Temp})+$ 0.112 (RNA:DNA $\times$ Temp) $-5.371\left(\mathrm{R}^{2}=0.88\right)$. Fish weight $\left(W_{i}\right)$ ( 61 to $425 \mathrm{mg}$ ) was not a significant covariate in this relationship.

\section{In situ RNA:DNA ratios and growth rates}

RNA:DNA ratios of juvenile stone flounder were generally higher in April than in March (Fig. 3). Juveniles from Stns 1 and 4 had the highest mean RNA:DNA ratios during both months. In situ growth rates of juvenile stone flounder, calculated from
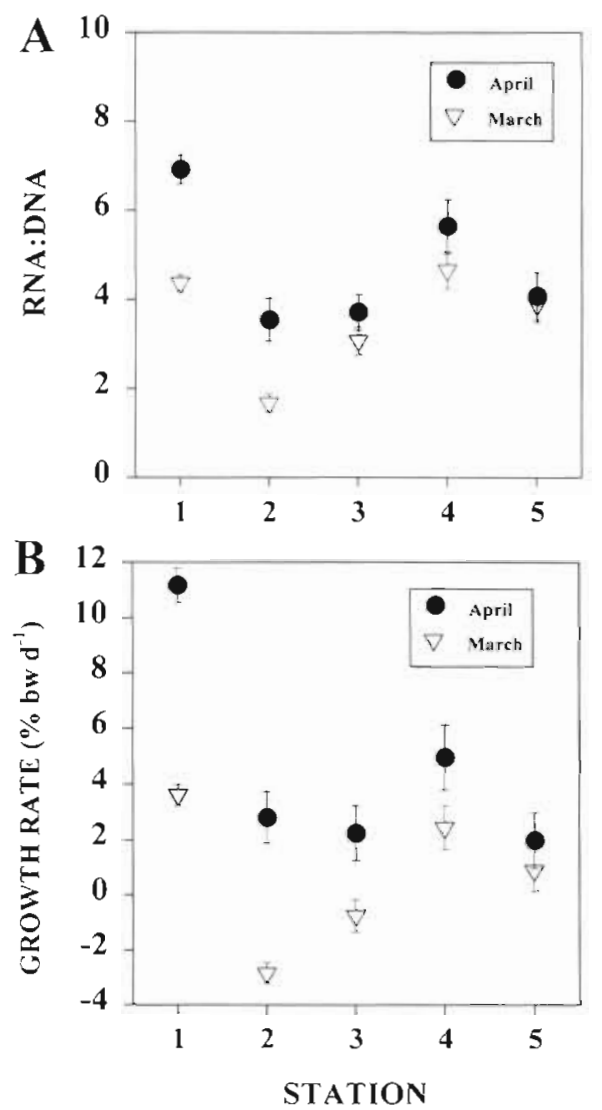

Fig. 3. Kareius bicoloratus. RNA:DNA ratios and specific growth rates (SGR) of juvenle stone flounder collected from 5 stations in and around Sendai Bay during March and April 1992. Points represent means \pm 1 SE. SGR were determined from RNA:DNA ratios and water temperature using the multiple regression equation described in the text. Sample sizes and collection dates given in Table 1

RNA:DNA ratios and water temperatures, were significantly higher in April than in March at all stations except Stn 5 (Fig. 3). During March, juveniles collected from Stns 1 and 4 had the highest mean growth rates, and those collected from the only vegetated habitat (Stn 2) had the lowest growth rate measured ( $1=4>5$ $>3>2$ ). A similar pattern was evident during April, when mean growth rates reached 11.5 and $5.0 \mathrm{~d}^{-1}$ at Stns 1 and 4 , respectively $(1>4>2=3=5)$.

To adjust for temperature differences among stations, growth rates were also plotted as the percentage of maximum (calculated from laboratory-derived temperature-growth relationships and water temperatures for each collection) (Fig. 4). In spite of temperature differences of 4 (March) to $8^{\circ} \mathrm{C}$ (April) among sampling stations, the temperature-corrected pattern of habitatspecific growth rates (Fig. 4) is similar to the pattern for the raw growth rate data (Fig. 3). Growth rates were all less than maximum in March, ranging from $64 \%$ of maximum at Stn 1 to negative growth rates at Stns 2 
and 3. Growth rates during April were above the expected maximums at Stns 1 and 4 , and about half of maximum at Stns 2, 3 and 5.

Densities of juvenile stone flounder ranged from 4.5 $1000 \mathrm{~m} 2$ (Stn 3, April) to $1635.21000 \mathrm{~m}^{-2}$ (Stn 4, March). Retention was highest at Stn 1 (25\%), and lowest at $\operatorname{Stn} 5(2.3 \%)[\operatorname{Stn} 1(25 \%)>\operatorname{Stn} 2(8.7 \%)>$ $\operatorname{Stn} 3(4.8 \%)>\operatorname{Stn} 4(3.1 \%)>\operatorname{Stn} 5(2.3 \%)]$, although no statistical evaluation was possible due to the lack of replicates. Instantaneous rates of density decrease at each station, which account for time differences between March and April sampling events, were ordered oppositely, indicating the same trend of increased retention at Stn 1 and lowest retention at Stn 5 (Table 1).

\section{Gut fullness and diet composition}

Samples sufficient for gut content analysis were only available from Stns 1, 2 and 4 (Table 3). Juvenile stone flounder gut fullness was highest at Stn 1, intermediate at Stn 4, and lowest at Stn 2 during both months (Table 3). Juveniles from all stations had fuller guts during April than during March. Copepods and polychaetes were the predominant prey items at all stations during both months, although ostracods and mysids were also important components of the diet at Stn 2. All copepods from fish at Stn 2 were small harpacticoids, while those in fish from Stns 1 and 4 were composed of both small harpacticoids and large calanoids. Bivalves were also important prey items of fish in April.

\section{DISCUSSION}

\section{Effects of temperature and ration on growth rates}

Juvenile stone flounder held in the laboratory grew at relatively fast rates ( 4 to $7 \%$ bw $\mathrm{d}^{-1}$ ) at the temperatures which characterize field conditions during and immediately following settlement $\left(8\right.$ to $\left.12^{\circ} \mathrm{C}\right)$. Therefore, growth potential appears to be high during the post-settlement period at ambient temperatures Growth rates of unfed juveniles were negative, but only moderate in magnitude and not significantly different between 8 and $12^{\circ} \mathrm{C}$, suggesting that weight loss due to starvation is relatively slow in fish at these typical sizes and temperatures during and subsequent to settlement. However, fish in the lab were fed ad libitum up until starvation, and lowered initial condition in the field may result in higher mortality and/or starvation rates over similar time periods. Newly settled stone flounder therefore appear to be poised to take advantage of favorable feeding conditions by losing weight slowly during periods of low prey availability, but retaining the metabolic capacity for rapid growth when prey becomes available. This energetic strategy was also observed in summer flounder Paralichthys dentatus, another temperate winter-spawned flatfish which relies on inshore estuarine nursery grounds (Malloy \& Targett 1994).

Specific growth rates under maximum feeding regimes increased very quickly over a relatively small temperature range $\left(>65 \%\right.$ increase over the $4^{\circ} \mathrm{C}$ range). Consequently, small spatial and temporal variations in temperature during and following settlement

Table 3. Kareius bicoloratus. Gut fullness (gut content wet weight/whole body wet weight $\times 100$ ) and gut contents (\% occurrence among all fish) of juvenile stone flounder collected from 3 stations in Sendal Bay, Japan. Station designations are the same as those in Table 1. Values are means (SD); $N=20$ fish for all stations except Stn $2(N=14$ in March, $N=16$ in April). Nem: Nematoda; Biv: bivalves or siphons; Poly: polychaeta; Cope: Copepoda; Cuma: Cumacea; Sip: Sipunculoidea; Mys: Mysidacea; Ostra: Ostracodai Gamma: Gammaridea

\begin{tabular}{|c|c|c|c|c|c|c|c|c|c|c|c|}
\hline \multirow[t]{2}{*}{ Stn } & & \multirow{2}{*}{$\begin{array}{c}\text { Gut } \\
\text { fullness }\end{array}$} & \multicolumn{9}{|c|}{$\%$ Occurrence } \\
\hline & & & Nem & Biv & Poly & Cope & Cuma & Sip & My's & Ostra & Gamma \\
\hline \multirow[t]{2}{*}{1} & March & $\begin{array}{c}1.687 \\
(0.717)\end{array}$ & 10 & 5 & 35 & 85 & 0 & 20 & 10 & 35 & 0 \\
\hline & Apnl & $\begin{array}{c}4.917 \\
(1.137)\end{array}$ & 20 & 40 & 100 & 75 & 0 & 35 & 0 & 5 & 15 \\
\hline \multirow[t]{2}{*}{2} & March & $\begin{array}{c}1.051 \\
(0.809)\end{array}$ & 28.6 & 14.3 & 14.3 & 64.3 & 0 & 0 & 0 & 71.4 & 0 \\
\hline & April & $\begin{array}{c}1.666 \\
(0.925)\end{array}$ & 18.8 & 25 & 12.5 & 100 & 0 & 0 & 56.3 & 62.5 & 18.8 \\
\hline \multirow[t]{2}{*}{4} & March & $\begin{array}{c}1.301 \\
(0.642)\end{array}$ & 10 & 5 & 75 & 30 & 15 & 0 & 0 & 0 & 15 \\
\hline & April & $\begin{array}{c}2.315 \\
(0.860)\end{array}$ & 25 & 30 & 95 & 25 & 15 & 0 & 0 & 0 & 0 \\
\hline
\end{tabular}



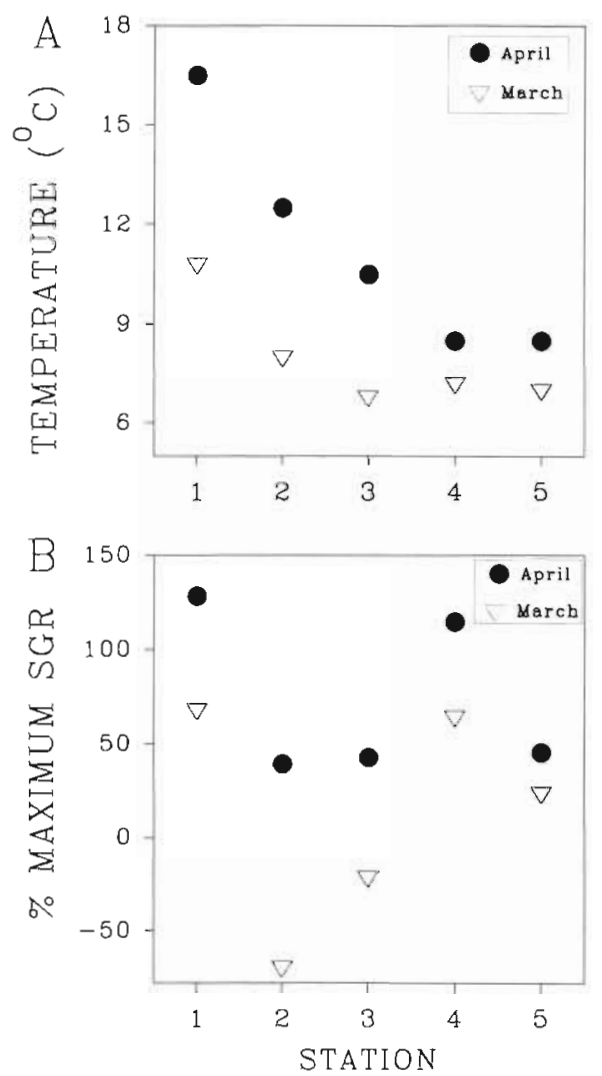

Fig. 4. Kareius bicoloratus. Water temperature and growth limitation ("\% maximum growth rate) of juvenile stone flounder collected from 5 stations in and around Sendai Bay during March and Aprll 1992. Percentage maximum growth rate was calculated as $\left(\mathrm{SGR}_{\text {in situ }} / \mathrm{SGR}_{\operatorname{mux}}\right) \times 100$, where $\mathrm{SGR} \ldots$.... is the mean growth rate for each station and date shown in Fig. 3 and $S G R_{\max }$ is the growth rate of juveniles feeding ad libitum calculated from the relationship between maximum growth rate and temperature (derived from laboratory experiments)

could have a dramatic effect on growth rates, and therefore on mortality rates and subsequent recruitment. Specific growth rates generally decrease with increasing body size, suggesting that the observed differences would have been even greater if the fish tested at $12^{\circ} \mathrm{C}$ had not been larger than those tested at $8^{\circ} \mathrm{C}$.

\section{RNA:DNA ratios as predictors of in situ growth rates}

RNA:DNA ratios provided estimates of in situ growth rates within the range expected based on laboratory experiments. Temperatures in the field ranged from 6.8 to $10.8^{\circ} \mathrm{C}$ during the peak in settlement in 1992 (March), and mean in situ growth rates ranged from -2.81 to $3.53 \%$ bw $d^{-1}$. During April, in situ growth rates ranged from 1.96 to 11.17 at temperatures between 8.5 and $16.5^{\circ} \mathrm{C}$. Although temperature was a significant covariate, the derived relationship between RNA:DNA ratio and specific growth rate provided reasonable growth rates and low within sample variability over the temperature range used in the lab $\left(8\right.$ to $\left.12^{\circ} \mathrm{C}\right)$. However, specific growth rates calculated from RNA: DNA ratios and water temperatures exceeded the maximum growth rates predicted in the laboratory at Stns $1\left(16.5^{\circ} \mathrm{C}\right)$ and $4\left(8.5^{\circ} \mathrm{C}\right)$ during April. Although the relationship between RNA:DNA ratios and growth rate is frequently less reliable at higher temperatures (i.e. $>16^{\circ} \mathrm{C}$ ), as suggested by several previous reports (Buckley et al. 1984, Malloy \& Targett 1994), RNA. DNA ratio relationships usually underestimate growth rate at higher temperatures, not overestimate them as was the case in the present study.

In situ water temperatures showed substantial diel variability corresponding to changes in air temperature, especially at shallow sites (e.g. maximum daily temperature changes among all sampling dates were $8.6^{\circ} \mathrm{C}$ at $\operatorname{Stn} 1$ and $5.2^{\circ} \mathrm{C}$ at $\operatorname{Stn} 2$ ). The temperatures used to calculate in situ growth rates were averages representative of the sites within 2 to $4 \mathrm{~h}$ of collection. Therefore, the 2 unexpectedly high values obtained for in situ growth rates might have resulted from overestimates of true mean water temperatures. Additionally, a few collections were made at temperatures outside those used to generate the RNA:DNA-growth rate relationship. Although in situ temperatures $(7.0$ to $16.5^{\circ} \mathrm{C}$ ) varied only a few degrees from those used in the laboratory $\left(8\right.$ to $\left.12^{\circ} \mathrm{C}\right)$, the apparent temperaturesensitivity of stone flounder growth rates suggest that even small temperature changes could result in significantly different growth responses.

\section{Spatial and temporal patterns of in situ growth rates}

Juvenile stone flounder grew relatively quickly immediately after settlement in almost all habitats sampled (except during March in the 2 Matsushima Bay habitats. Stns 2 and 3), although growth rates were significantly different among the 5 habitats sampled. Mean growth rates were higher in April than in March at almost all sites, suggesting that higher water temperatures later in the spring were accompanied by consistently high or elevated numbers of prey. This hypothesis is supported by higher gut fullness at all stations during April (even though the fish were larger in April and had higher gut capacities than in March). although gut fullness data are somewhat limited. Higher growth rates and gut fullness in April may also be due to larger juveniles being able to forage on larger and more diverse prey items.

Specific growth rates of field-caught juveniles were highest at Stn 1, the only estuarine habitat sampled, 


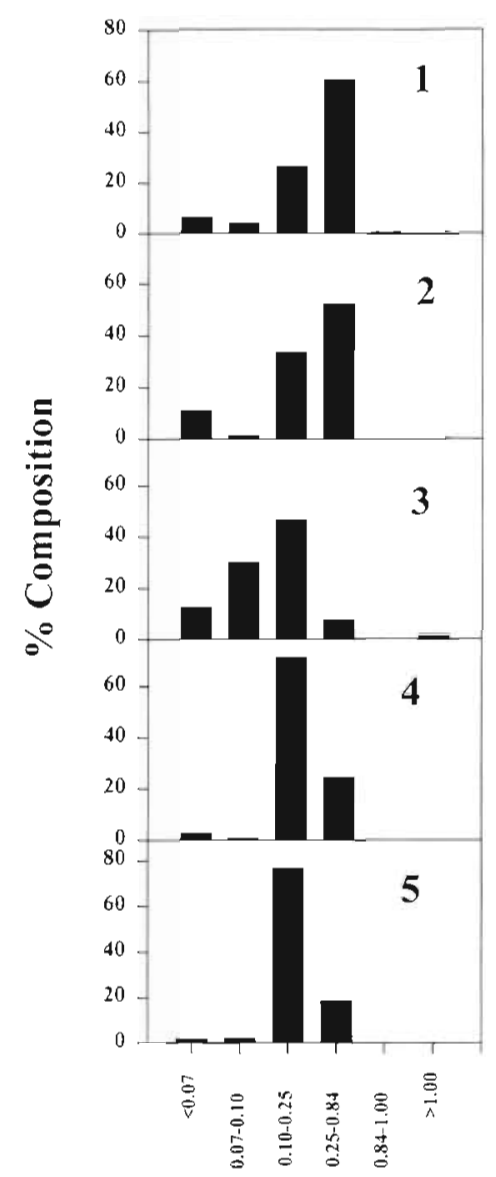

Grain Size $(\mathrm{mm})$

Fig. 5. Grain size composition of bottom sediments at 5 stations in and around Sendai Bay. Compositions were determined by separating sediments into size classes with sieves and calculating the relative proportion (by dry weight) of each fraction. Stations numbers are the same as those in Table 1

during both March (3.6\% bw d $\mathrm{d}^{-1}$ ) and April (11.2\% bw $\left.\mathrm{d}^{-1}\right)$. This station also had the highest juvenile stone flounder retention $25.6 \%$ between March and April), suggesting that emigration and/or mortality was lowest at this site. This station was an estuarine nursery ground characterized by the coarsest sediments, lowest salinity and highest temperatures of any habitat sampled (see Table 1, Fig 5). High temperatures and adequate prey abundances were probably responsible for much of the dramatically higher growth rates observed at Stn 1. Although quantitative estimates of prey populations are not known, gut fullness was higher at this station than at any of the stations measured in this study. Additionally, this station had the largest sediment grain sizes, which are associated with higher flounder prey densities (Omori \& Tsuruta 1988)
Stn 1 also received sufficient freshwater inputs to maintain salinities of $\sim 3$ to $16 \%$, lower than all of the other stations sampled. Several studies have documented a significant metabolic cost of osmoregulation (Moser \& Hettler 1989, Abud 1992), and ambient isosmotic conditions may allow a larger scope for growth by reducing the metabolic costs of osmoregulation. Preliminary laboratory studies show that juvenile stone flounder are very tolerant of low salinity (100\% survival after 48 h at $<2 \%$; Tsuruta pers. comm.), but the effects of salinity on growth rates have not been investigated.

The remaining stations were influenced primarily by oceanic water in Sendai Bay, including the seagrass bed habitat in Matsushima Bay (Stn 2), and 3 deeper inshore areas (Stns 3 to 5). Growth rates at Str 4 ranked second behind Stn 1 during both months, and were notably higher than growth rates at the other deep stations. Stn 4 was almost identical to Stn 5, which was also relatively deep and characterized by cooler, high salinity water, but fish at $\operatorname{Stn} 5$ had much lower growth rates. Sediments at Stns 4 and 5 were also similar; somewhat smaller than those at Stn 1 (Fig. 5). However, Stn 4, unlike Stn 5, was in close proximity to a sewagetreatment plant outfall $2 \mathrm{~km}$ to the south (Abukuma River Sewage Treatment Plant). Prey densities at Stn 4 may be higher than those at other, similar open water areas in Sendai Bay (Abukuma River Sewage Office 1990-1994). In the present study, the retention at $\operatorname{Stn} 4$ was extremely low (3.1\% retention), similar to that at Stn $5(2.3 \%)$, suggesting that emigration to shallower inshore nurseries and/or mortality rates were substantially higher offshore than those at Stn 1. Newly settled stone flounder are known to actively immigrate inshore at night on flood tides (Tsuruta 1991), and the temporal decrease is probably partially a result of emigration to inshore areas.

One surprising result was the consistently low growth rates observed in the only vegetated habitat sampled, Stn 2. Zostera spp. beds have been shown repeatedly to be favorable habitats for juveniles of several species, presumably due to higher prey densities and their function as predation refuges (e.g. Sogard \& Able 1991). Stn 2 contained very high densities of Zostera spp. and primarily ( $>85 \%$ ) coarse sediments similar to those at Stn 1 (where growth was highest of all stations sampled) (Fig 5). However, the sediments in the Zostera spp, bed appeared to be stratified, with finer sand covering the coarser-grained sediments, which may account for the apparently low prey densities (inferred from gut fullness data). It is also possible that dense vegetation cover actually reduces the available habitat area of juvenile flounder, which usually prefer to bury in the sediments and adopt a sit-andwait foraging strategy, or stalk prey in discrete bursts 
of swimming followed by settlement and reburial. Sogard (1992) also found that juvenile winter flounder inhabiting Zostera spp. beds in New Jersey (USA) estuaries grew less quickly than juveniles in other habitats. She speculated that factors such as temperature and sediment structure might account for the observed lack of enhanced flatfish growth in vegetated habitats.

Sediment characteristics may also be partly responsible for the observed pattern of habitat-specific growth rates in April. Juvenile stone flounder appear to prefer coarser sediments, since they are found predominantly in habitats containing sediments larger than $0.25 \mathrm{~mm} \varnothing$ (Omori \& Tsuruta 1988). We observed a similar correlation between stone flounder densities and sediment grain size (see Table 1, Fig. 5). Other species of flatfish have also been found to display a preference for sediment grain size. For example, Burke (1991) found that juvenile summer flounder Paralichthys dentatus in the laboratory preferred coarsergrained sand over finer-grained mud, even if food was available only in less-preferred sediments. Energetics studies have shown that the metabolic rates of flatfishes can increase significantly when the fish are forced to bury in sediments with suboptimal grain sizes or do not have access to sediments at all (Peyraud \& Labat 1962, Howell \& Canario 1987). Two other western Pacific flatfish species have also shown a preference for sediment types in which they could most easily bury (Tanda 1990). Presumably, selection has resulted in flatfishes with sediment preferences which minimize metabolic costs of burying as well as optimize their ability to forage and hide from predators. Other characteristics of sediments, such as color and organic content, have also been found to be important habitat characteristics for juvenile flatfishes (Burke 1991), but these factors were not addressed in this study.

Juvenile stone flounder growth rates were found to be higher in this study (during April) and others in habitats containing larger-grained sediments (Omori \& Tsuruta 1988). Omori \& Tsuruta (1988) speculated that this pattern was correlated with the abundance and composition of benthic invertebrates which comprise important infaunal prey items, which decrease with decreasing grain sizes of bottom sediments in Sendai Bay (Omori 1975, Omori \& Tsuruta 1988). Omori \& Tsuruta (1988) demonstrated that juvenile stone flounder had higher growth rates and stomach fullness when caged on larger sediments $(45.5 \%>0.25 \mathrm{~mm}$ diameter) than when held over smaller sediments $(16.4 \%>$ $0.25 \mathrm{~mm})$, further suggesting that sediment-specific growth and distribution patterns may reflect patterns of optimal prey distribution.

In general, growth limitation was more severe during March $1<0$ to $64 \%$ predicted maximum growth rate) than during April (43 to $>100 \%$ predicted maximum), in spite of the higher temperatures and therefore higher maximum potential growth rates in April. Flounder densities were approximately an order of magnitude lower in April than in March at each station, and gut fullness was higher. Therefore, the relative prey abundance (i.e. prey/flounder ratio) may have been higher in April

Although the magnitude of growth limitation changed between March and April, spatial patterns in growth limitation among sampling habitats remained very similar during both months. Growth limitation, therefore, seems to be a function of habitat characteristics, but not a function of the temperature or prey population cycles. Sogard (1992) also observed that different habitats seemed to maintain consistent growth potentials for different species and over long time periods (years). Habitat characteristics at Stns 1 and 4 seem to be suited to high growth rates in juvenile stone flounder, although the dramatic decreases in density observed in these habitats between March and April suggests that mortality/emigration in these habitats is substantial.

\section{Potential importance of predation to habitat quality}

Although growth rates and gut contents were the only factors used to infer the relative importance of different habitats as stone flounder nursery grounds in the present study, other factors, such as predation rates, are also likely to be important in determining optimal nursery habitats. Predation likely constitutes a large fraction of overall juvenile mortality, and the variables determining optimal predation refuges may differ from those resulting in high growth rates. For example, although juveniles collected from Zostera spp. beds had the lowest growth rates observed, they may have lower overall mortality rates due to decreased predation rates. In fact, overall retention at the Zostera spp. site (Stn 2) was second highest among the 5 stations in this study. Rapid growth does facilitate lowered mortality rates, but several studies have documented that juvenile fishes will select habitats that offer enhanced protection from predators while sacrificing optimal foraging and/or growth rates (e.g. Werner et al. 1983). Although the predatory crangonid shrimp Crangon affinis is less abundant in Zostera spp. beds (Table 1), it is unknown if vegetated, inshore habitats afford any protection from piscivorous predators such as gobiid fishes. Sogard (1992) and our data suggest that for flatfish, which rely heavily on burrowing and feeding on benthic invertebrates, vegetated habitats may not represent an optimal predation refuge or foraging habitat. 
Low salinity habitats also tend to have lower abundances and generally smaller sizes of Crangon affinis. Predation by $C$. affinis has been observed in the laboratory, and juvenile stone flounder otoliths have been found in the guts of $C$. affinis (Yamashita et al. in press), which can reach densities of almost $1 \mathrm{~m}^{-2}$ on sandy bottoms at depths $>10 \mathrm{~m}$ in Sendai Bay (Table 1). Therefore, inshore nursery areas may not unly provide higher temperatures and increased prey availability which facilitate rapid growth, but may be important predation refuges as well. Additional work examining the importance of sediment characteristics (i.e. grain size, color) and the presence of vegetation to predation rates is needed to better understand the value of different nursery areas to this species

Acknowledgements. We are grateful to Drs M. Omori and $\mathrm{H}$. Honda of Tohoku University and to Dr Y Tsuruta of the Japanese Fisheries Agency, who gave us invaluable information. This is BIOCOSMOS Project of the Ministry of Agriculture, Forestry and Fisheries, Japan, contribution no. BCP94IV-C-3.

\section{LITERATURE CITED}

Abud EO Aristizabul (1992) Effects of salinity and weight on routine metabolism in the juvenile croaker, Micropogonias furnieri (Desmarest 1823). J Fish Biol 40:471-472

Abukuma River Sewage Office (1990-1994) Annual report of the effects of discharge water from the sewage disposal plant on the physical, chemical and biological characteristics of Ninokura waters. Abukuma River Sewage Office. Miyagi Prefecture Government, Japan (in Japanese)

Bailey KM, Houde ED (1989) Predation on eggs and larvae of marine fishes and the recruitment problem. Adv mar Biol 25:1-83

Bindoo M (1992) Influence of size and level of satiation on prey handling time in Channa striata (Bloch). J Fish Biol 40:497-504

Buckley JJ, Turner SI, Halavk TA, Smigielski AS, Drew SM, Laurence GC (1984) Effects of temperature and food availability on growth, survival and RNA-DNA ratio of larval sand lance (Ammodytes americanus). Mar Ecol Prog Ser 15:91-97

Buckley LJ, Bulow FJ (1987) Techniques for the estimation of RNA, DNA and protein in fish. In: Summerfelt RC, Hall GE (eds) The age and growth of fish. The lowa State University Press, Ames, p 345-354

Burke JS (1991) Influence of abiotic factors and feeding on habitat selection of summer and southern flounder during colonization of nursery grounds. PhD dissertation, North Carolina State University, Raleigh

Burke JS, Miller JM, Hoss DE (1991) Immigration and settlement patterns of Paralichthys dentatus and Paralichthys lethostigma in an estuarine nursery ground, North Carolina, U.S.A. Neth J Sea Res 27:393-405

Cushing DH (1974) The possible density-dependence of larval mortality and adult mortality in fishes. In: Blaxter JHS (ed) The early life history of fish. Springer-Verlag, Berlin, p 103-112

Cushing DH (1975) Marine ecology and fisheries. Cambridge University Press, Cambridge
Folkvord A, Hunter JR (1986) Size specific vulnerability of northern anchovy, Engraulis mordax, larvae to predation by fishes. US nat mar Fish Serv Fish Bull 84:859-869

Ghan D. Sprules WG (1993) Diet, prey selection and growth of larval and juvenile burbot Lota lota. J Fish Biol $42: 47-55$

Goto $T$, Sudo H, Tomiyama M, Tanaka M (1989) Settling poriod of a flounder, Paralichthys olvaceus, larvae and juveniles in Shijiki Bay, Hırado Island. Nıppon Suisan Gakk 55(1):9-16 (in Japanese with Englısh summary)

Houde ED (1987) Fish early life dynamics and recruitment variability. Am Fish Soc Symp 2:17-29

Houde ED (1989) Subtleties and episodes in the early life of fishes. J Fish Biol 35 (Suppl A):29-38

Howell BR, Canario AVM (1987) The influence of sand on the estimation of resting metabolic rate of juvenile sole Solea solea (L.). J Fish Biol 31:277-280

Kaeding LR, Osmundson DB (1988) Interaction of slow growth and increased early-life mortality: an hvpothesis on the decline of Colorado squawfish in the upstream regions of its historic range. Environ Biol Fish 22:287-298

Kuipers B (1975) On the efficiency of a two-meter beam trawl for juvenile plaice (Pleuronectes platessa). Neth J Sea Res 9.69-85

Lankford TE, Targett TE (1994) Sultability of estuarine nursery zones for juvenule weakfish (Cynoscion regalis) effects of temperature and salinity on feeding growth and survival. Mar Biol 119:611-620

Malloy KD, Targett TE (1991) Feeding, growth and survival of juvenile summer tlounder Paralichthys dentatus: experimental analysis of the effects of temperature and salinity. Mar Ecol Prog Ser 72:213-223

Malloy KD, Targett TE (1994) The use of RNA:DNA ratios to predict growth limitation of juvenile summer flounder (Paralichthys dentatus) from Delaware and North Carolina estuaries. Mar Biol 118:367-375

May RC (1974) Larval mortality in marine fishes and the critical period concept. In: Blaxter JHS (ed) Early life history of fish. Springer-Veriag, New York, p 3-19

Minam. T (1984) The early life history of a flounder Kareius bicoloratus. Bull Jap Soc Scient Fish 50(4):551-560 (in Japanese with English summary)

Moser ML, Hettler WF (1989) Routine metabolism of juvenile spot Leiostomus xanthurus (Lacepede), as a function of temperature, salinity and weight. J Fish Biol 35: $703-707$

Omori M (1975) A study on the production ecology of demersal fishes in Sendai Bay - II. Interspecific relationships concerning habitat and food. Bull Jap Soc Scient Fish 41(6):615-629 (in Japanese with Enclish summary)

Omori M, Kinno $H$, Nishihata I (1976) Study of the habitat of juvenile stone flounder, Kareius bicoloratus (Basilewsky), in the estuary of the Nunakita River. Tohoku J agricult Res 27(2):79-91

Omori $M$. Tsuruta $Y(1988)$ The ecology of stone flounder in estuarine-coastal area. In: Kurihara Y (ed) Ecology and ecotechnology in estuarine-coastal area. Tokai Univ Press, Tokyo, p 111-118 (in Japanese)

Orth RJ, Heck IL Jr (1980) Structural components of eelgrass (Zostera marina) meadows in the lower Chesapeake Bay - fishes. Estuaries 3:278-288

Peyraud C, Labat R (1962) Réactions cardio-respiratoires observées chez la sole au cours de l'ensablement. Hydrobiologia 19:351-356

Post JR, Evans DO (1989) Experimental evidence of sizedependent predation mortality in juvenile vellow perch. Can J Zool 67:521-523 
Rozas LP, Odum WE (1988) Occupation of submerged aquatic vegetation by fishes: testing the roles of food and refuge. Oecologia 77:101-106

Sissenwine MP (1984) Why do fish populations vary? In: May $\mathrm{R}$ (ed) Exploitation of marine communities. SpringerVerlag, Berlin, p 59-94

Smith PE (1985) Year-class strength and survival of 0-group clupeids. Can J Fish Aquat Sci 42 (Suppl 1):69-82

Sogard SM (1992) Varrability in growth rates of juvenile fishes in different estuarine habitats. Mar Ecol Prog Ser 85: $35-53$

Sogard SM, Able KW (1991) A comparison of eelgrass, sea lettuce macroalgae, and marsh creeks as habitat for epibenthic fishes and decapods. Estuar coast Shelf Sci 33 $501-519$

Tanda M (1990) Studies on burying ability in sand and selection to the grain size for hatchery-reared marbled sole and Japanese flounder. Nippon Suisan Gakk 56:1543-1548

Tsuruta Y (1978) Field observations on the immigration of larval stone flounder into the nursery ground. Tohoku $\mathrm{J}$ agricult Res 29(3/4):136-145

This article was submitted to the editor
Tsuruta Y (1991) Migrating mechanism of the larval stone flounder, Karelus bicoloratus, into the nursery ground. Bull Tohoku Natl Fish Res Inst 53:49-58 (in Japanese with English summary)

Werner EE, Gilliam JF, Hall DJ, Mittelbach GG (1983) An experimental test of the effects of predation risk on habitat use in fish. Ecology 64:1540-1548

Yamashita $Y$, Yamada $H$, Malloy KD, Targett TE, Tsuruta $Y$ (in press) Sand shrimp predation on settling and newlysettled stone flounder and its relationship to optimal nursery habitat in Sendai Bay, Japan. In: Watanabe $Y$, Yamashita Y, Oozeki Y (eds) Survival strategies in early life stages of marine resources. AA Balkema, Rotterdam

Yusa $T$ (1981) Early life history of stone flounder, Kareius bicoloratus. Rapp P-v Réun Cons int Explor Mer 178: 595-596

Yusa T, Kyushin K, Forrester CR (1977) Outline of life history information on some manne fish. Res Inst $\mathrm{N}$ Pac Fish, Hokkaido Univ Spec Vol (December 1977):123-173

Zar JH (1984) Biostatistical analysis. Prentice Hall, Englewood Cliffs, NJ

Manuscript first received: December 19, 1994

Revised version accepted: August 3, 1995 